Article

\title{
Little value creation, articulation and propagating forces: A hypothesis for the Mexican manufacturing sector
}

\author{
Santiago Roca T. ${ }^{\mathrm{a}, *}$, Luis Simabuko N. ${ }^{\mathrm{b}}$ \\ a Centro de Propiedad Intelectual, Competencia, Consumidor y Comercio, Cepic, Graduate School of Business, Universidad ESAN, Lima-Peru. Ph.D. Cornell University \\ ${ }^{\mathrm{b}}$ Research fellow, Graduate School of Business, Universidad ESAN, Lima-Peru
}

\section{A R T I C L E I N F O}

\section{Article history:}

Received 9 October 2014

Accepted 21 August 2015

\section{JEL classification:}

014

025

038

054

F1

Keywords:

Industrialization

Technological change

Industrial policy

Trade

Latin America

\begin{abstract}
A B S T R A C T
This paper evaluates the impact of Mexican trade and productive integration processes during the last 20 years. It finds evidence that growing per capita income in Mexico is directly related to its "trade opening", but is inversely related to the growth of its manufacturing export industry. Specifically, for each point of growth in "trade opening" (as a proportion of GDP) per capita income grew by $0.22 \%$; while each point of increase in the share of industrial exports reduced income per person by $0.09 \%$.

To explain this apparent contradiction between the positive effect of "trade opening" and the negative impact of productive manufacturing specialization, we examined the characteristics of Mexico's industry. Results show that although Mexico's export-led industrialization successfully adapted to the world market and transformed its productive, business, organizational and technological structure, it did not translate into adequate macroeconomic benefits due to the absence of strong value dissemination forces over the rest of the economy.

In this sense, poor internal linkages in the maquila industry, its high propensity to import, and its limited value added generation, among other elements, led the Mexican industry to operate as an export enclave. In those circumstances, manufacturing does not generates positive externalities nor articulations, nor strong disseminations that increase and multiplies value in other sectors of industry, thus limiting expansion effects and restraining or even reducing-under some specific circumstances-per capita income growth.
\end{abstract}

(C) 2015 Universidad ESAN. Published by Elsevier España, S.L.U. This is an open access article under the CC BY-NC-ND license (http://creativecommons.org/licenses/by-nc-nd/4.0/).

\section{Escasez de la creación de valor, articulación y fuerzas de propagación: una hipótesis para el sector manufacturero de México}

\section{R E S U M E N}

Este documento evalúa el impacto del comercio y los procesos de integración productiva de México durante los últimos veinte años. Aporta evidencia acerca de que el crecimiento de la renta per cápita en México se halla directamente relacionado con su "apertura comercial", aunque guarda una relación inversa con el crecimiento de su industria de exportación manufacturera. De modo específico, para cada punto de crecimiento de la "apertura comercial" (como proporción del PIB), la renta per cápita creció un $0.22 \%$, mientras que cada punto de incremento de la cuota de exportaciones industriales redujo la renta per cápita en un $0.09 \%$.

Para explicar esta aparente contradicción entre el efecto positivo de la "apertura comercial" y el impacto negativo de la especialización manufacturera productiva, examinamos las características de la industria mexicana. Los resultados muestran que aunque la industrialización impulsada por la exportación de México se ha adaptado exitosamente al mercado mundial, transformando su estructura productiva, comercial, organizativa y tecnológica, ello no se ha traducido en los beneficios macroeconómicos adecuados, debido a la ausencia de unas sólidas fuerzas de diseminación del valor sobre el resto de la economía.

\footnotetext{
* Corresponding author.

E-mail address: sroca@esan.edu.pe (S. Roca T.).
} 
En este sentido, los débiles vínculos internos en la industria de maquila, su elevada propensión a la importación, y su limitada generación de valor añadido, entre otros elementos, han llevado a la industria mexicana a operar como un enclave exportador. En estas circunstancias, la fabricación no genera externalidades ni articulaciones, ni fuertes diseminaciones que incrementen y multipliquen el valor en otros sectores de la industria, limitando, por tanto, los efectos de expansión, así como restringiendo, e incluso reduciendo, bajo circunstancias específicas, el crecimiento de la renta per cápita.

(C) 2015 Universidad ESAN. Publicado por Elsevier España, S.L.U. Este es un artículo Open Access bajo la licencia CC BY-NC-ND (http://creativecommons.org/licenses/by-nc-nd/4.0/).

\section{Introduction}

This paper evaluates the impact of Mexican trade opening and productive specialization on per capita income. It specifically analyses how trade opening and specialization in manufacturing exports has affected per capita income.

Standard international trade theory assumes that trade opening will automatically make countries better off. Some of the major developing economists argue this is not necessarily true, opening and specialization in raw materials may reduce instead of increase standards of living. Many of them say that it is only through industrialization that income per capita will increase. This paper tests these different hypotheses. The second section briefly summarizes the economic literature on trade opening, and productive specialization and growth. The third section estimates the impact of trade opening and specialization on Mexican economic growth. Sections four and five explain major empirical findings: how trade opening has increase GDP per capita and why specialization in manufacturing exports has had a significant negative contribution to per capita income. Finally, the paper draws some major conclusions regarding conditions for better economic growth.

\subsection{Trade opening and growth}

There are several reasons why "trade opening" and commercial exchanges in general favor economic growth.

- First, trade permits local companies to buy foreign goods, services, inputs, machinery and equipment, and technology, not available locally or available at a greater cost.

- The second is that opening of trade allows for the introduction of new ideas, new forms of entrepreneurial organizations and various types of management techniques.

- Third, trade opening eventually allows small countries to increase their exports and to gain access to broader markets, with which they could increase their income levels.

- Fourth, broader markets could also have greater possibilities to benefit from economies of scope and scale and from the international division of labor (Krugman, 1991).

- Related to the previous idea is that broader market leads to larger R\&D spending, which accelerates technological change and economic growth (Romer, 1990).

- Finally, a more open business environment creates more competition in the internal market, increasing the efficiency of local firms compared to when there are restrictions to international trade.

Diverse empirical works based on econometric analysis (Dollar, 1992; Sachs \& Warner, 1995; Edwards, 1992) have come across evidence of the positive relationship between trade opening and economic growth. For example, Dollar and Kraay (2001) estimate that an increase in the volume of trade (as \% of GDP) by 20 percent results in an increase in the annual growth rate between 0.5 and $1 \%$. Other empirical investigations -based themselves on gravity models - try to isolate and separate the net impact of "trade opening" from other structural and institutional factors.
For example, Frankel and Romer (1999) consider the gravity model and some demographic factors; Dollar and Kraay (2003), consider the gravity model plus social, historical and institutional variables.

\subsubsection{Productive specialization and growth}

Diverse springs of economic thought consider that the type of specialization (productive specialization) determines economic growth. That is, economic activities are not equivalent creators of value, nor they are neutral at all. The common denomfinator of all these theories is that certain economic activities are preferable to others due to some intrinsic or extrinsic qualities than other sectors lack. One of these is the work by Graham (1923) who demonstrates that:

- In a world of two countries, if one country specializes in goods with increasing returns and the other country in goods with decreasing returns, the world will overall have increased income, but the level of the second country's income will be diminishing, while the first country's income will be increasing.

- Moreover, the level of income for both countries will be greater if and only if the two countries produce with similar returns.

Graham, like many of his predecessors of past centuries, was of the opinion that the use of raw materials has intrinsically decreasing returns, while the production of manufactured products presents increasing returns.

In the middle of the past century, Prebisch and Singer, for example, showed that countries specializing in natural resources hurt themselves because the price of these products grow relatively more slowly than the price of manufactured products, due to the smaller income elasticity of the former and the asymmetry of international markets. For Hirschman, agriculture lacks upstream and downstream links or the complex division of labor current in manufacturing. Myrdal speaks about "cumulative causations" present in manufacturing but absent in natural resources based industry.

In the 1990s, Matsuyama (1992) and other authors said that manufacturing presents positive effects for growth absent from agriculture, resulting from bigger "induced learning" that neither agriculture nor the service sector offer. Sachs and Warner (1995a) and Sala-i-Martin (1997) found that economies specializing in goods production and exports on the basis of intensive natural resources use tend to grow slightly more slowly than those exporting manufactured products. While for Sachs and Warner the reason should have been the poor development of the institutions created by a primary exporting economy, for Sala-i-Martin the interpretation of these results is not very clear.

Reinert (2002), from a Schumpeterian perspective, argues that economic activities are qualitatively different in the way technological progress spreads and in the way benefits from this progress are distributed, and that this difference determines economic growth and income inequality among nations. For this reason, he proposes a "quality index" of economic activities where high quality jobs show increasing returns, imperfect competition, steep learning curves, rapid technological changes and large 

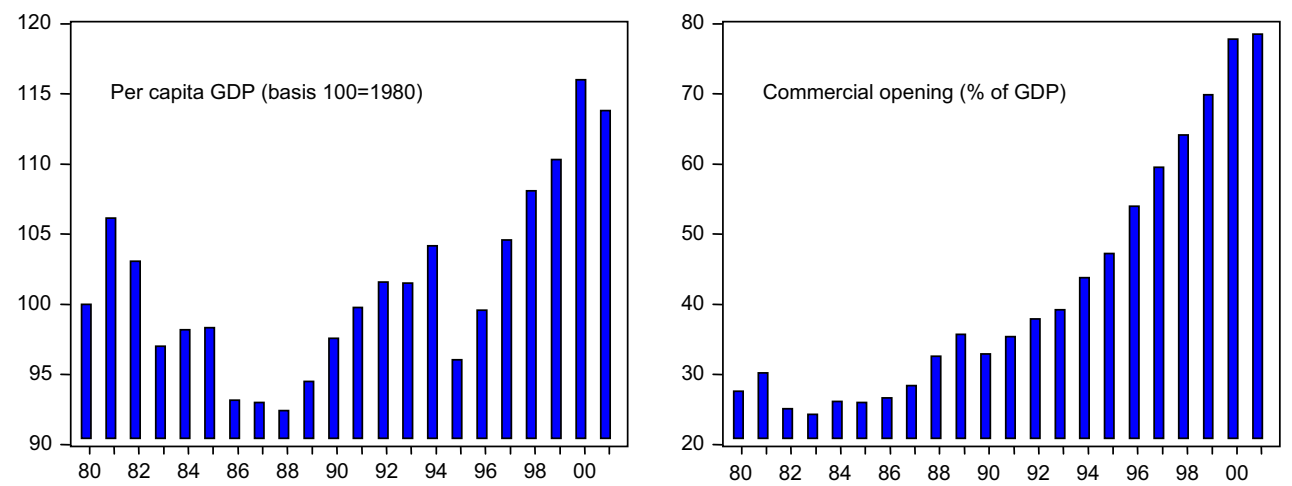

Figure 1. Mexico's per capita GDP and trade opening, 1980-2001.

Source: CEPAL.

investments in R\&D, while, in the lower level, low quality jobs show decreasing returns, perfect competition, relatively flat learning curves, little technological development and low investment in R\&D. Reinert concludes that the present industrial economies have elected, actively and consciously, high quality activities while non-industrial economies are stuck with low quality activities.

Empirical works like that of the IDB show that "countries where the exports with intermediate and high technological content represent $10 \%$ of GDP tend to grow between 0.1 and 0.2 percent more than others that, other factors being equal, do not export this type of goods" (IDB 2001: 55). Likewise, Ros' work found that "for similar initial income and investment rate, the countries that specialize in manufacturing exports grew from 1960-1990 at a faster rate than exporters of primary products" (Ros, 2001).

Finally, from the perspective of general economic specialization and not of trade specialization, Roca and Simabuko, 1999; Roca and Simabuko, 2004 found that in the Peruvian economy of 1950-1997, for each percentage point of primary goods growth, per capita consumption fell by $2.6 \%$ and real wages and salaries fell by $5.4 \%$ and $7.4 \%$, respectively. However, for each additional percentage point in manufacturing, per capita consumption rose by $4.2 \%$ and real wages and salaries increased by $10.6 \%$ and $15.5 \%$, respectively. In the construction sector, positive impacts were also estimated, although notoriously lower than the estimates for industry. Lastly, in services, the impact is estimated close to zero.

In general, most supporters of the non-neutrality of countries' productive specialization, think manufacturing or industrial specialization seems preferable to development based on the exploiting the natural resource base. Higher quality activities are ranked as such not only for their potential to create greater value, but also for their potential to add value to the system as a whole, through their synergies, externalities, links and other strong value propagators.

\section{Impact of trade opening and productive specialization on Mexican economic growth}

\subsection{PBI per cápita, trade opening and exports}

In the eighties, Mexico's per capita income showed an oscillating but decreasing trajectory (Figure 1), especially in the second fiveyear period where there was a visible fall of 6\% between 1986 and 1988. In the nineties, the evolution of this indicator was much more encouraging, as it grown at an average annual rate of $1.7 \%$, only interrupted between 1995 and 1996 due to the country's financial and foreign exchange crisis.

Throughout the eighties, Mexico's trade opening $(\mathrm{M}+\mathrm{X}) / \mathrm{PBI}$ stayed at an average below $30 \%$ of GDP, but a rapid and continued liberalization and trade opening led at the end of the nineties to an opening exceeding $70 \%$ of GDP, after increasing integration of the North American market through NAFTA.

As regards the makeup of exports (Figure 2), between 1980 and 2000, a strong backward movement of primary exports was observed, and that reduced their share from $81 \%$ to $12 \%$. This smaller participation of primary exports was possible at the expense of a larger export industry, especially those industrial goods disseminating technological progress, like machinery and equipment, which came to represent from 1\% of exports in 1980 to $40 \%$ in 2000 . Another strong growth area was the export of durable consumer goods, like electrical appliances and vehicles, which grew from $2 \%$ to $23 \%$, and the traditional export industries, like food, beverages and tobacco, that increased from $6 \%$ to $18 \%$.

\subsection{A simple GDP per capita regression model}

To analyze the relationship between PBI per capita, trade opening and productive specialization, a single time series model is proposed where the dependent variable is the per capita GDP and

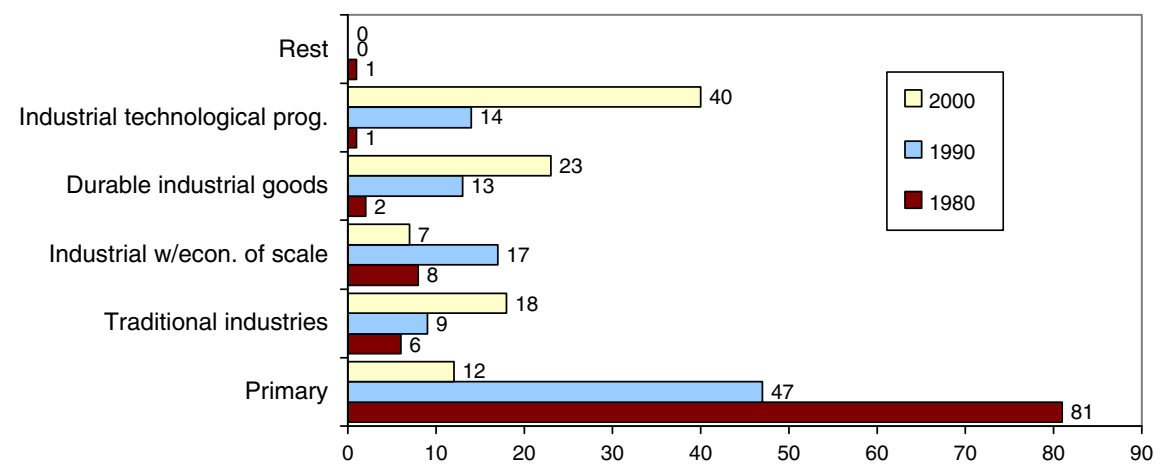

Figure 2. Composition of Mexico's export goods (\%). 
Table 1

Correlation matrix (in differences).

\begin{tabular}{|c|c|c|c|c|c|c|c|c|}
\hline & MX_GDPP & MX_OPEN & MX_PRIM & MX_IND & MX_IND1 & MX_IND2 & MX_IND3 & MX_IND4 \\
\hline MX_GDPP & 1.000000 & 0.475860 & 0.388112 & -0.380737 & -0.218498 & -0.484013 & -0.285297 & -0.129123 \\
\hline MX_OPEN & & 1.000000 & 0.079591 & -0.074995 & 0.058069 & -0.053707 & -0.300095 & -0.007256 \\
\hline MX_PRIM & & & 1.000000 & -0.999688 & -0.905582 & -0.153885 & -0.560867 & -0.847991 \\
\hline MX_IND & & & & 1.000000 & 0.907615 & 0.142681 & 0.551458 & 0.856604 \\
\hline MX_IND1 & & & & & 1.000000 & -0.097999 & 0.463260 & 0.836140 \\
\hline MX_IND2 & & & & & & 1.000000 & 0.079384 & -0.295404 \\
\hline MX_IND3 & & & & & & & 1.000000 & 0.255019 \\
\hline MX_IND4 & & & & & & & & 1.000000 \\
\hline \multicolumn{9}{|c|}{ Variables in the Mexican economy } \\
\hline \multicolumn{2}{|l|}{ MX_GDPP } & \multicolumn{7}{|c|}{ GDP per capita (basIS $1980=100$ ) } \\
\hline \multicolumn{2}{|l|}{ MX_OPEN } & \multicolumn{7}{|c|}{ Trade opening (\% del GDP) } \\
\hline \multicolumn{2}{|l|}{ MX_PRIM } & \multicolumn{7}{|c|}{ Share of primary exports (\%) } \\
\hline \multicolumn{2}{|l|}{ MX_IND } & \multicolumn{7}{|c|}{ Share of industrial exports (\%) } \\
\hline \multicolumn{2}{|l|}{ MX_IND1 } & \multicolumn{7}{|c|}{ Share of traditional industrial exports (\%) } \\
\hline \multicolumn{2}{|l|}{ MX_IND2 } & \multicolumn{7}{|c|}{ Share of industrial exports with economies of scale (\%) } \\
\hline \multicolumn{2}{|l|}{ MX_IND3 } & \multicolumn{7}{|c|}{ Share of exports of industrial durable goods (\%) } \\
\hline \multicolumn{2}{|l|}{ MX_IND4 } & \multicolumn{7}{|c|}{ Share of exports of industrial technological progress diffusers goods (\%) } \\
\hline
\end{tabular}

Elaborated by the author.

the independent or explanatory variables are trade opening and specialization in manufacturing activities. The model to be estimated is the following:

$\ln \mathrm{GDPP}_{t}=a 0+a 1 \ln \mathrm{OPEN}_{t}+a 2 \ln S P E C_{t}+e_{t}$

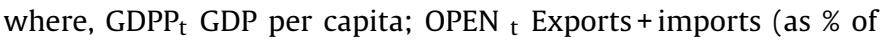
GDP); $S P E C_{t}$ Productive specialization: Exports of industrial products (as \% of the total export of goods); $e_{t}$ Other variables that affect the GDP per capita.

Both per capita GDP and the indicator of trade opening are calculated in real dollars; while exports composition follows CEPAL's breakdown as: 1) primary exports, 2) industrial exports, and 3) rest. CEPAL subdivides the industrial exports category into: 1 ) traditional, 2) goods presenting significant economies of scale and high intensity of natural resources, 3) durable goods, and 4) technological progress diffuser goods. (Cepal, 2003; Cepal, 2003a). (See CEPAL's export classification and data base on Appendix A and Appendix B at the end of this article).

\section{Regression 1}

\section{Sample 1981-2000}

relationship is observed between per capita income and the participation of industrial exports on the country's total exports goods (MX_IND). Consistently enough a positive relationship is observed between per capita income and the share of primary exports (MX_PRIM) in total exports (See Appendix C).

Moreover, the negative relationship between income per capita and the industrialization of Mexican exports is observed in diverse industrial indicators, as in the case of traditional industrial exports (MX_INDI), products with economies of scale (MX_IND2) (Appendix C), durable goods (MX_IND3) and technological development diffuser products (MX_IND4).

Having taken into account the observed relationships, the estimated equation for the Mexican economy is: $\mathrm{D}\left(\mathrm{LOG}\left(\mathrm{MX} \_G D P P\right)\right)=\mathrm{a} 1 \quad \mathrm{D}\left(\mathrm{LOG}\left(\mathrm{MX} \_\right.\right.$OPEN $\left.)\right)+\mathrm{a} 2$ D(LOG(MX_IND)) + a3 D95 (Regression 1). This regression captures approximately $74 \%$ of the increase of per capita GDP between 1981 and 2000 and has as explanatory variables: 1) trade opening, 2) share of industrial exports and 3) a dummy variable D95 representing the 1995 Mexican crisis.

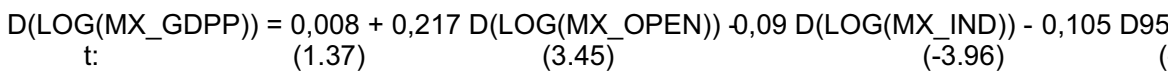

R2: 0.74

R2a: 0.69

F: $15.15(0.00)$

DW: 1.39

In agreement with the trade opening and productive specialization theories on the previous section, the two hypotheses to evaluate are the following:

Hypothesis I. a1 $>0$. Trade opening positively affects economic growth.

Hypothesis II. a2 $>0$. Export specialization in industrial activities has a positive impact on economic growth.

The correlation matrix for primary differences (see Table 1) shows a positive relationship between the increase of per capita income (MX_GDPP) and the level of trade openness (MX_OPEN), which is in agreement with economic theory premises that a larger trade opening drives economic growth. However, a negative
According to these results, the primary hypothesis is confirmed, i.e. trade opening drove Mexico's economic growth between 1980 and 2000; however, the second hypothesis is rejected, in the sense that Mexican industrial exports has a negative relationship with per capita GDP growth.

It is estimated that for each growth point in trade opening (as a share of GDP) the per capita income grew $0.22 \%$; while for each extra point in the share of industrial exports, the income per person decreased by $0.09 \%$. Because the relative negative impact of productive specialization is smaller in absolute terms than that of trade opening, the final impact on the growth of Mexican economy remains positive.

From another perspective, if instead of using in model regression the share of manufacturing exports, we used the share of 


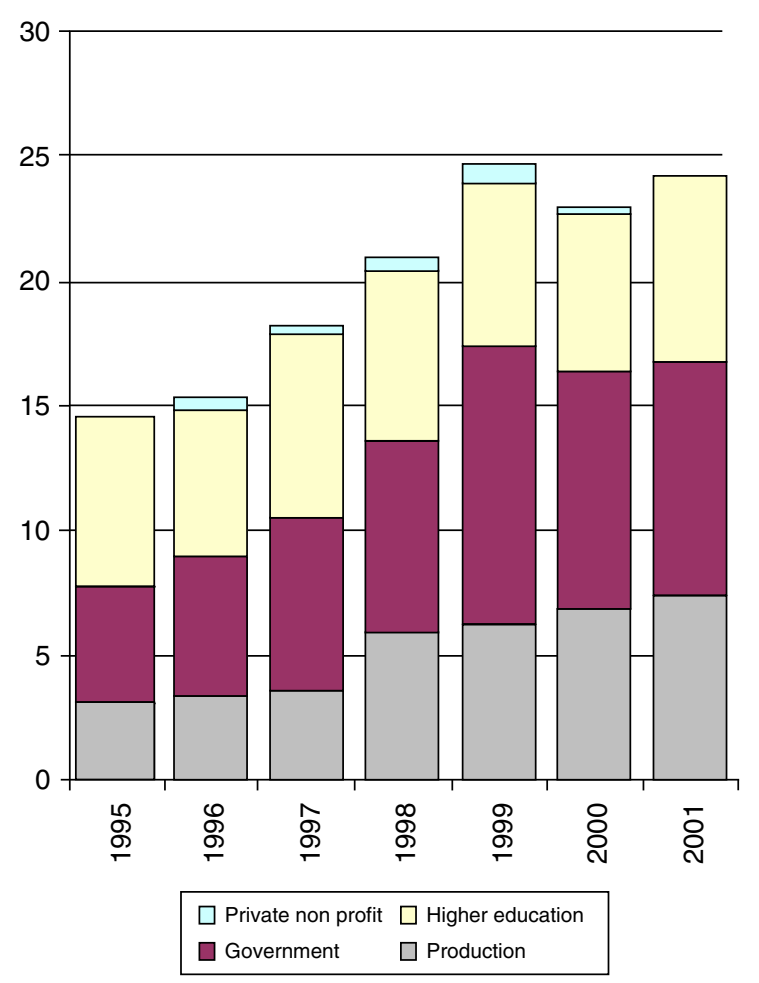

Figure 3. Experimental R\&D. Mexico (millions of pesos). Source: CONACYT.

primary exports, the relationship between this variable with per capita GDP is positive (significant at $11 \%$ ) and with a value of $0.06 \%$. (See regression 2 below). This means that the increase in the share of natural resource exports will involve -in the case of Mexico- an increase of per capita GDP of $0.06 \%$. This result openly questions the hypothesis that "specialization in raw materials-based production contributes less to the increase of production than producing manufactured goods". In Mexico the exact opposite occurs. A preliminary explanation of this apparent contradiction with the literature and empirical evidence from other countries (mentioned in the previous section), relates to the specific characteristics of the natural resources sector in Mexico. It may be that the generation of rents in the use of natural resources is so high that on average it exceeds the value creation offered by new manufactured export goods. This indicates that Mexican agriculture and natural resources goods are still in a production zone with growing returns, economies of scale and rent levels that are significantly higher than other production sectors, including manufacturing. Additionally, quite likely its downstream links have a larger domestic multiplier affect than the new links created by the new types of manufactured export goods. The following section analyzes in more detail some of these probable links from the point of view of the potential to create value in the present Mexican manufacturing industry.

\section{Regression 2}

\section{Sample 1981-2000}

Table 2 using regression 1 shows the components of Mexico's average economic growth in the eighties against the nineties. It shows that the $7 \%$ overall increase of per capita income (between the eighties and the nineties) is explained by the positive contribution from trade opening (13.6\%), the negative contribution of productive specialization $(-6.7 \%)$ and the net positive impact of other factors ${ }^{1}(0.1 \%)$. This means that Mexico's per capita GDP growth (7\% between these two decades) is fundamentally explained by the trade opening capacity to neutralize and compensate for the negative impact of the productive specialization.

\section{How does trade opening increases GDP per capita?}

In general, more open trade favors economic growth to the extend it allows countries to access larger markets and to dispose of new technologies, inputs, ideas, and management, which improve firm efficiency and drive economies of scale and scope in productive activities. In this sense, the growth of Mexico's export industry is largely explained to the signing of the Free Trade Agreement with the United States and Canada (NAFTA) and the development of the maquila industry that goes back, originally, to the Border Industrialization Program of the seventies.

It is clear that NAFTA allowed Mexico free access to 317 million persons (5.2\% of world population) with an import capacity of about 1.4 billion dollars (22\% of world imports and 9 times Mexican exports). Most importantly is that the Mexican economy took advantage of this preferential access placing itself in ten years among the main trade partners of the United States. This greater commercial exchange was correlated to larger investment flows, given that US firms (looking for efficiency and cost reduction) heavily invested in the Mexican manufacturing sector as a way to effectively compete in its own market with Asian's automobiles, electrical appliances, garments and other imports.

To provide goods to the North American market Mexico had accordingly to restructure its productive sector to the new trends and composition of US and world demand. The Mexican economy changed its export structure originally based in natural resources intensive goods towards a structure based on medium and high technology industrial goods. This new Mexican export development was coherent with last 20 years observed changes in world trade as well as the huge productive transformations of successful export industrializing countries like Ireland and Singapore (see Table 3).

Obviously enough to change its productive structure Mexico had to open itself to greater volumes of imports with higher technological components and productivity (Table 4). Specifically in the last 20 years, imports of industrial goods acting as diffusers of technological progress (machinery and equipment) increased from an annual average of 5.9 billion dollars in the first half of the eighties (36.5\% of the total imports) to 54.9 billion dollars in the second half of the nineties ( $41.7 \%$ of the imports).

$$
\begin{aligned}
& \mathrm{D}\left(\text { LOG }\left(M X \_G D P P\right)\right)=0.006+0.223 \mathrm{D}\left(\text { LOG }\left(M X \_O P E N\right)\right)+0.06 \mathrm{D}(\text { LOG }(M X+P R I M))-0.101 \mathrm{D} 95 \\
& \mathrm{t}: \quad(0.43) \quad(2.73)^{-} \quad(1.67) \quad(-3.59)
\end{aligned}
$$

R2: 0.56

R2a: 0.48

F: $6.83(0.00)$

DW: 1.28 
Table 2

Contribution to GDP per capita growth Average in the eighties against the nineties.

\begin{tabular}{|c|c|c|c|c|}
\hline & $\begin{array}{l}\text { 1981-1990 } \\
\text { average }\end{array}$ & $\begin{array}{l}\text { 1991-2000 } \\
\text { average }\end{array}$ & Elasticity & $\begin{array}{l}\text { Weighted contribution the } \\
\text { eighties against the nineties }\end{array}$ \\
\hline Trade opening (1) & $29 \%$ & $53 \%$ & 0,217 & $13,6 \%$ \\
\hline Productive specialization (2) & $40 \%$ & $82 \%$ & $-0,090$ & $-6,7 \%$ \\
\hline Other (residual) $(3)=(4)-(2)-(1)$ & & & & $0,1 \%$ \\
\hline Total = GDP per capita $(4)$ & 97,3 & 104,2 & & $7,0 \%$ \\
\hline
\end{tabular}

Estimation based on regression 1.

Elaborated by the author.

Table 3

Export structure by countries (\%)

\begin{tabular}{|c|c|c|c|c|c|c|c|c|}
\hline & \multicolumn{2}{|c|}{ World market 1 / } & \multicolumn{2}{|c|}{ Mexico 2/ } & \multicolumn{2}{|c|}{ Ireland $3 /$} & \multicolumn{2}{|c|}{ Singapore 4/ } \\
\hline & 1980 & 1998 & 1986 & 2000 & 1985 & 1998 & 1985 & 1998 \\
\hline Natural resources & 25,6 & 15,1 & 45,5 & 12,6 & 20,5 & 6,9 & 4,4 & 1,5 \\
\hline Manufactures based on natural resources & 18,7 & 11,6 & 12,5 & 6,0 & 24,1 & 33,4 & 38,2 & 14,5 \\
\hline Manufactures not based on natural resources & 55,8 & 73,4 & 41,7 & 81,0 & 53,5 & 57,7 & 54,0 & 80,2 \\
\hline Of low technology & 14,2 & 16,8 & 8,7 & 15,2 & 15,2 & 11,5 & 8,7 & 4,6 \\
\hline Of medium technology & 31,0 & 34,3 & 23,6 & 37,6 & 15,4 & 11,4 & 17,5 & 14,8 \\
\hline Of high technology & 10,6 & 22,3 & 9,4 & 28,2 & 22,9 & 34,8 & 27,8 & 60,8 \\
\hline Others & -- & -- & 0,3 & 0,3 & 1,9 & 2,0 & 3,3 & 3,9 \\
\hline Total & 100,0 & 100,0 & 100,0 & 100,0 & 100,0 & 100,0 & 100,0 & 100,0 \\
\hline
\end{tabular}

1/BID, 2001.

2/CEPAL, 2003

3/Mortimore, Vergara and Katz, 2001

4/Mortimore, Vergara and Katz, 2001

Table 4

Mexican imports by five-year periods (millions of dollars).

\begin{tabular}{|c|c|c|c|c|}
\hline & 1981-85 & $1986-90$ & 1991-95 & $1996-00$ \\
\hline Industrial technological progress diffusers goods $(\mathrm{A})$ & 5925 & 6677 & 23059 & 54885 \\
\hline Totals (B) & 16234 & 19881 & 63364 & 131576 \\
\hline $\mathrm{A} / \mathrm{B}(\%)$ & $36,5 \%$ & $33,6 \%$ & $36,4 \%$ & $41,7 \%$ \\
\hline
\end{tabular}

Source: INEGI (www.inegi.gob.mx)

Experimental real terms R\&D expenses grew 67\% between 1995 and 2001, in particular expenses in the production sector $(+143 \%)$ and government (+97\%). Likewise, the R\&D workforce expanded by $32 \%$, with the productive sector absorbing the largest part of this increment through growth of $185 \%$ (Figures 3 and 4 ).

These increases in imports and in R\&D spending and workforce had positive repercussions in the levels of productivity in the manufacturing sector. Although the low absolute level of average productivity of Mexico's labor in comparison to the developed countries is well known, it is estimated that between 1993 and 2002, labor productivity in the Mexican manufacturing sector (excluding maquila activities) experienced a $54 \%$ increase, or slightly less than in the United States $(+58 \%)$, but above Germany (+45\%), Japan (+24\%), Canada (+15\%) and the United Kingdom $(+15 \%)$. This is an indication that, despite the large differences of productivity in absolute terms that still exist, Mexico has managed to increase its productivity at a faster pace than most industrialized countries (Table 5). South Korea shows the largest productivity increase of all, at about $133 \%$.

Concerning the exporting maquila industry, various research studies pointed out that through the years Mexican maquila is moving from the old-coined style (old textile industry) to the newly-coined maquila more related to electric and electronic appliances, and the mecatronics and electronics components industry (Alonso, Carrillo \& Contreras, 2002). This process clearly shows that industrial organization, production methods, and labor training among many other variables are experimenting dramatic structural changes in this sector (opus cit).

While the old-coined maquila has almost no impact on business development, since these organizations hardly perform operational administrative activities and process engineering, the newlycoined maquila undertakes much more complex activities (see Table 6). For example, in the electric and electronic appliances industry, in addition to the ordinary old style assembly processes,

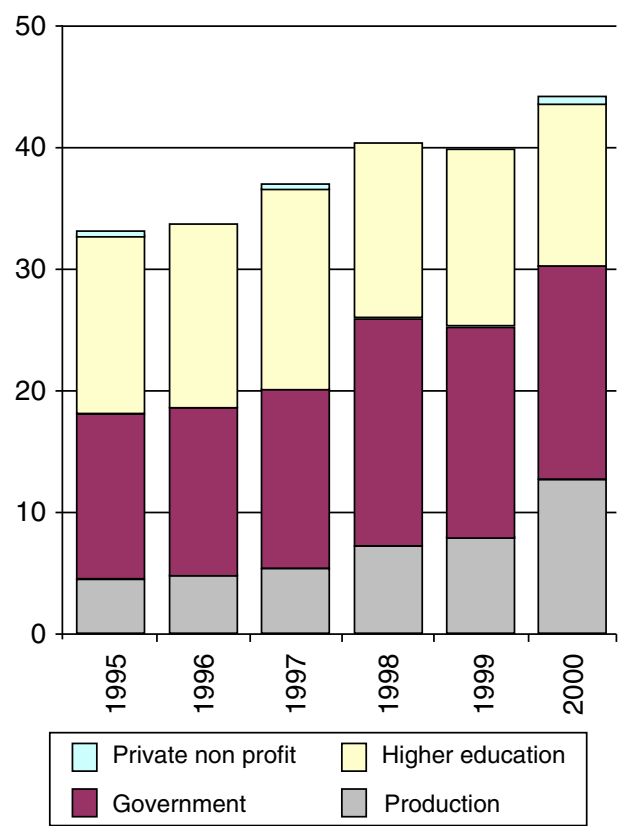

Figure 4. R\&D workforce growth (thousand of equivalent full time. Source: CONACYT. 
Table 5

Index of labor productivity in manufacturing (Basis $100=1993$ ).

\begin{tabular}{|c|c|c|c|c|c|c|c|}
\hline & Mexico */ & United States & Canada & Japan & Germany & Korea & United Kingdom \\
\hline 1993 & 100,0 & 100,0 & 100,0 & 100,0 & 100,0 & 100,0 & 100,0 \\
\hline 1994 & 109,9 & 103,2 & 104,7 & 103,2 & 111,0 & 110,1 & 103,6 \\
\hline 1995 & 115,3 & 108,3 & 109,1 & 107,8 & 113,6 & 122,2 & 102,5 \\
\hline 1996 & 125,7 & 113,6 & 108,2 & 111,7 & 118,5 & 134,8 & 102,1 \\
\hline 1997 & 130,9 & 120,5 & 108,6 & 117,5 & 127,3 & 147,0 & 103,1 \\
\hline 1998 & 136,4 & 128,1 & 112,5 & 113,3 & 131,1 & 158,7 & 103,3 \\
\hline 1999 & 139,0 & 136,4 & 117,6 & 117,0 & 133,9 & 192,3 & 107,3 \\
\hline 2000 & 145,7 & 144,3 & 118,3 & 123,8 & 142,6 & 212,3 & 112,5 \\
\hline 2001 & 146,8 & 148,2 & 113,2 & 119,8 & 143,0 & 213,6 & 114,2 \\
\hline $2002 \mathrm{p} /$ & 153,6 & 158,0 & 114,5 & 123,8 & 145,3 & 232,8 & 114,9 \\
\hline
\end{tabular}

Excluding maquila. $\mathrm{P}=$ Preliminary

Source: INEGI (www.inegi.gob.mx).

Table 6

Mexican maquila: Typology of production organization models.

\begin{tabular}{|c|c|c|c|c|c|}
\hline Functions Organization models & Operations management & Process Engineering & Product Engineering & Design & R\&D \\
\hline Assembly - traditional & * & - & - & - & - \\
\hline Continuous manufacturing/assembly - traditional & * & / - & */- & - & - \\
\hline Manufacturing-traditional specs & ${ }^{*}$ & $*^{*}$ & $*$ & * $1-$ & - \\
\hline Continuous manufacturing - edge & * & * & $*^{\prime}$ & $*$ & - \\
\hline Manufacturing - edge specs & $*$ & * & * & & * \\
\hline
\end{tabular}

* $=$ present

- = absent

/- = present only for greater product complexity

Source: Alonso, Carrillo and Contreras, 2002; p. 26.

the authors identify product engineering and design activities. Likewise, in addition to the activities already described, the electronic and mechatronic industry also performs R\&D activities, which involve a greater business and technological development, and labor training, among other more complex functions and/or activities (Alonso, Carrillo \& Contreras, 2002).

In summary, this section has analyzed various transmission mechanisms through which "trade opening" is positively impacting economic growth. In the Mexican case it is particularly relevant to point up the role play by NAFTA and the maquila industry. Both allowed access to a larger preferential market and propelled a significant restructuring of exports towards medium and high technology industrial activities. Nonetheless these "trade opening" positive effects, there is also evidence that the greater export of manufactures affected negatively economic growth. More about this last point will be analyze in the next section.

\section{Why specialization in manufacturing exports does not increase GDP per capita?}

The most controversial finding of the present study is the negative relationship between industrial exports and per capita GDP. This relation is in conflict with the idea that export industrialization per se should bring an increase in GDP per capita. In the case of Mexico each additional point of participation of industrial exports to total exports originates a $0.09 \%$ reduction in per capita income per year.

What factors explain this negative relationship between the industrial exports and per capita income? The answer will be explored studying the nature of the Mexican export industry, which for the sake of a more simple analysis, will be define by the characteristics of the maquiladora industry.

Why a "successful" industrialization -in terms of adaptation to the world market and company and technology transformation among other aspects explained in section $3-$ is counterbalanced in its macroeconomic benefits by these negative forces?

In general and to a great extent, nothing guarantees that specialization in labor intensive activities or even in high technological industrial exports benefits the economy as a whole if those activities (Some of these theses are proposed by UNCTAD (2001):

- Develop in world market segments that may saturate quickly, and consequently where prices may drop as a tendency.

- Fail to develop a more profound division of labor and a highly trained specialized technological workforce.

- Create limited internal and inter-industry links or few ties with the local companies, which will arrest the potential benefits of its growth from spreading to the rest of the economy.

- Provide limited potential for disseminating or diffusing the lessons learned to other sectors.

- Be accompanied by a gradual increase of value added by the activity involved and by the entire productive system.

- Base its competitiveness exclusively on low salaries. If so, sector growth would be self-defeating as it would increase salaries and, therefore, eradicate the presumed competitive advantage of labor.

From the analysis of these six factors, we have information that proves that the growth of Mexican industrial exports failed at least on three accounts: 1) limited industrial links, 2) little growth in value added and, 3) growth largely based on comparative advantage provided by cheap labor. These three factors are analyzed in

Table 7

Inputs bought by Mexican maquila (as \% of GVP).

\begin{tabular}{llll}
\hline & Imports & Domestic & Total \\
\hline 1980 & 69.3 & 1.2 & 70.5 \\
1985 & 75.1 & 0.7 & 75.8 \\
1990 & 74.8 & 1.3 & 76.1 \\
1995 & 80.8 & 1.4 & 82.2 \\
1996 & 81.4 & 1.7 & 83.1 \\
1997 & 79.8 & 1.8 & 81.6 \\
1998 & 78.4 & 2.2 & 80.6 \\
1999 & 76.6 & 2.4 & 79.0 \\
2000 & 75.6 & 2.4 & 78.0 \\
2001 & 73.1 & 2.7 & 75.8 \\
\hline
\end{tabular}

Source: CEPAL, 2003; p. 13. 


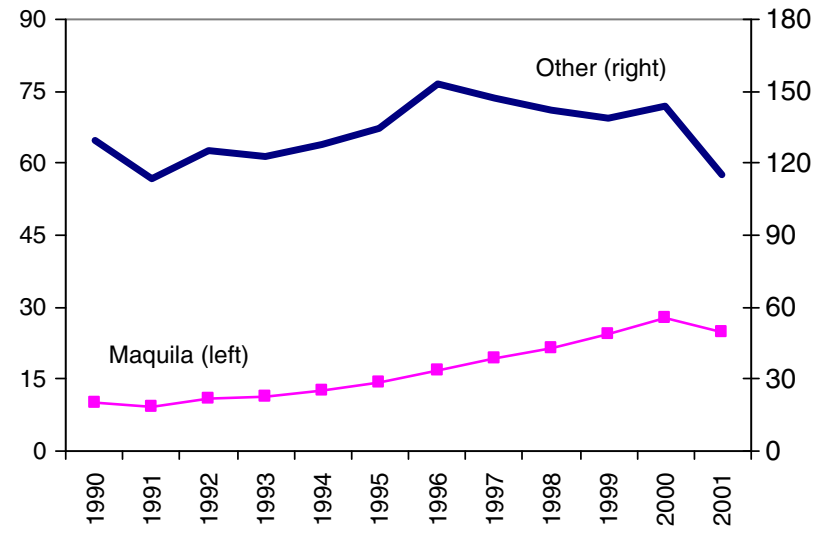

Figure 5. Value added. Maquila and other manufacturing industries. (Billion of 1993 pesos)

Source: INEGI (www.inegi.gob.mx).

detail below. Other three issues need further research and statistical information.

In Table 7, purchases of imported inputs account for between $70 \%$ and $80 \%$ of Gross Value of Production (GVP), while the weight of domestic inputs is extremely small since it does not exceed 3\% of GVP. Since the maquila industry's import propensity has not changed significantly in the last 20 years, this sector has failed to develop as an integrated productive system and therefore its internal links remain very limited.

Likewise, an analysis of inter-industrial links reveals that an increase in maquiladoras value added derives from stagnation or slow growth in other manufacturing industries. This reveals lack of links and complementarities with other activities. In the nineties, while the maquila industry's value added grew $179 \%$, value added in other manufacturing sectors grew only $11 \%$ (Figure 5 ).

These two facts explain part of the decreasing tendency of per capita income. Progress by the maquila sector will mean -in practice- replacing the traditional productive system that in theory shows better internal linkages and bases its advantages on natural resources (like in the food, beverage, textile, etc. industries), for another new productive system (like the maquila) that shows less internal linkages. In this process to re-structure economic activities, positive externalities from the retreating sector will be lost, with a less than proportional gain in the externalities of the expanding sector. The net balance of recomposing these economic activities would be negative -according to the regressions estimated in this study.

On the other hand value added in the maquila industry, as a share of its GVP decreased until the mid-nineties ${ }^{2}$, to then bounce back slightly up to 2001, but still at a level below 1980 (see Table 8). Wages and profits the main components of value added, follow a similar path as total VA. Consequently, by 2001 neither of these variables had returned to their 1980 values. In general, in the last 20 years, no remarkable increase was observed in this sector's capacity to create value added. It is unlikely therefore that it will make a contribution to economic growth in any significant way.

Finally, regarding maquila industry competitiveness and investments, Mexican studies by Buitelaar, Padilla, \& Urrutia, 1999, show that the principal determinant of these investments is cheap labor -especially by North American companies ${ }^{3}$.

\footnotetext{
2 Explained, in part, by the Mexican financial crisis that occured in 1995.

3 Other reasons to be considered are preferential access to the North American market (especially, by companies that are not North American), greater profit rates, reduced risk, and tax breaks.
}

Table 8

Composition of VA in Mexican maquila (as \% of GVP).

\begin{tabular}{lllll}
\hline & Wages & Profits & Rest & Total \\
\hline 1980 & 18.2 & 5.1 & 7.4 & 30.7 \\
1985 & 12.8 & 4.8 & 7.3 & 24.9 \\
1990 & 13.0 & 4.1 & 8.1 & 25.2 \\
1995 & 9.4 & 2.8 & 7.0 & 19.2 \\
1996 & 9.0 & 2.4 & 7.2 & 18.6 \\
1997 & 10.0 & 2.7 & 7.5 & 20.2 \\
1998 & 10.5 & 3.0 & 8.1 & 21.6 \\
1999 & 11.4 & 3.3 & 8.7 & 23.4 \\
2000 & 12.4 & 2.7 & 9.3 & 24.4 \\
2001 & 13.3 & 3.5 & 10.1 & 26.9
\end{tabular}

Source: CEPAL, 2003; p. 13.

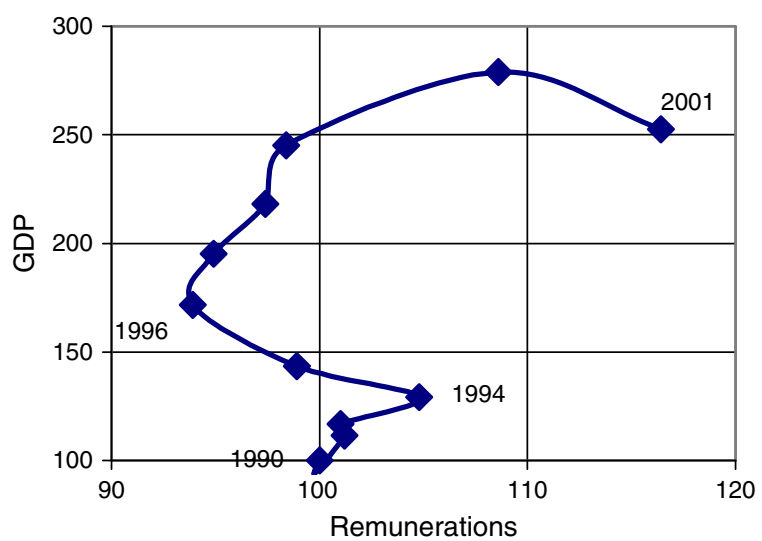

Figure 6. Maquila's real remunerations and GDP (Basis $1990=100$ ).

Source: Prepared by the authors with INEGI data from www.inegi.gob.mx.

Table 9

Maquila's real wages and maquila's GDP (\% change).

\begin{tabular}{llll}
\hline & Remunerations & GDP & Elasticity \\
\hline $1994 / 1990$ & $4.8 \%$ & $29.1 \%$ & 0.81 \\
$1996 / 1994$ & $-10.4 \%$ & $32.9 \%$ & 0.67 \\
$2001 / 1996$ & $23.9 \%$ & $47.1 \%$ & 0.84
\end{tabular}

Source: Own elaboration with INEGI data from www.inegi.gob.mx.

An analysis of evolving real wages in the maquila and its GDP (or VA) in the last 10 years (Figure 6) reveals significant fluctuations in wages, while output rose uninterruptedly except in 2001. Between 1990 and 1994, the average remuneration in the maquila industry increased by $4.8 \%$ in real terms, but the financial crisis of 1995 led to a $10.4 \%$ fall in the following two years. Between 1996 and 2001 wages grew a strong 23.9\%. Maquila's GDP increased over the whole period.

Table 9 compares this behavior of wages with output growth over the same periods. Estimating a wage to output elasticity indicates that remunerations grew proportionally less than the maquila's GDP. The wage to output elasticity numbers are below 1 (0.81, 0.67, 0.84 and 0.46 for indicated periods).

Although the above data does not point to a clear growth bottleneck, it does indicate that the sector's wages will continue to be competitive, since wages are growing more slowly than value added. Productivity increases are higher than wage increases.

\section{Conclusions}

This paper evaluates the impact of Mexican trade and productive integration process during the last 20 years. It finds evidence that growing per capita income in Mexico is directly related to its "trade opening", but is inversely related to the growth of its 
manufacturing export industry. Specifically, for each point of growth in "trade opening" (as a proportion of GDP) per capita income grew by $0.22 \%$; while each point of increase in the share of industrial exports reduced income per person by $0.09 \%$. It shows that the $7 \%$ overall increase of Mexican per capita income between the eighties and the nineties is explained by 13,6 points from trade opening, $-6,7$ points from specializing in manufacturing exports and 0,1 points from other factors.

To explain this apparent contradiction between the positive effect of "trade opening" and the negative impact of productive manufacturing specialization, we examined the characteristics of Mexico's industry. Results show that although Mexico's exportled industrialization successfully adapted to the world market and transformed its productive, business, organizational and technological structure, it did not translate into adequate macroeconomic benefits due to the absence of strong value dissemination forces over the rest of the economy.

In this sense, poor internal linkages in the maquila industry, its high propensity to import, and its limited value added generation, among other elements, led the Mexican industry to operate as an export enclave. In those circumstances, manufacturing does not generates positive externalities nor articulations, nor strong disseminations that increase and multiplies value in other sectors of industry, thus limiting expansion effects and restraining or even reducing - under some specific circumstances- per capita income growth.

\section{Appendix A. International trade classification categories}

\begin{tabular}{|c|c|c|c|}
\hline CATEGORY & EXAMPLES OF PRODUCTS & CONSUMPTION DESTINATION & CUCI $\underline{a} /$ \\
\hline $\begin{array}{l}\text { A. Primary goods } \\
\text { 1. Agriculture } \\
\text { 2. Mining } \\
\text { 3. Energy }\end{array}$ & $\begin{array}{l}\text { Fish, legumes, fruits, wood, } \\
\text { wool, minerals, oil. }\end{array}$ & Final or intermediate. & $\begin{array}{l}\text { Agriculture: } 001,025,031,041,0421,043,044,045,051,054 \text {, } \\
0711,0721,074,075,121,211,212,2211,2212,2213,2214,2215 \text {, } \\
2216,2217,2218,2311,241,242,244,261,2621,2622,2623, \\
\text { 2625, 2631, 264, 265, 2711, 291, 292. } \\
\text { Mining: } 2712,2713,2714,273,274,275,276,281,283,285,286 . \\
\text { Energy: } 321,331,341 .\end{array}$ \\
\hline $\begin{array}{l}\text { B. Industrial goods } \\
\text { 1. Traditional products } \\
\text { a) Food, beverages, and } \\
\text { tobacco } \\
\text { b) Other traditional } \\
\text { products }\end{array}$ & $\begin{array}{l}\text { Dairy products, oil, sugar, } \\
\text { woven fabric, tools, } \\
\text { furnishings, footwear, printed } \\
\text { matter, leather. }\end{array}$ & Final & $\begin{array}{l}\text { Food, beverages and tobacco: } 011,012,013,022,023,024,032, \\
0422,046,047,048,052,053,055,061,062,0713,0722,0723, \\
073,081,091,099,111,112,122,2219,411,422,431 . \\
\text { Other traditional products: } 2313,2314,243,2511,2626,2627, \\
2628,2629,2632,2633,2634,267,551,611,612,613,621,631, \\
632,633,642,6511,6512,6513,6514,6515,6518,6519,652,653 \text {, } \\
654,655,656,657,662,663,665,666,667,691,692,693,694,695, \\
696,697,698,733,812,821,831,841,842,851,892,893,894,895, \\
897,899 .\end{array}$ \\
\hline $\begin{array}{l}\text { 2. Goods with economies of } \\
\text { scale and high natural } \\
\text { resources intensity }\end{array}$ & $\begin{array}{l}\text { Petrochemicals, paper, pulp, } \\
\text { cement, basic metals and } \\
\text { industrial commodities. }\end{array}$ & Intermediate & $\begin{array}{l}\text { Goods with economies of scale and high natural resources } \\
\text { intensity: } 2312,2512,2515,2516,2517,2518,2519,266,282, \\
284,332,421,512,513,514,515,521,531,532,533,554,561,571 \text {, } \\
5811,5812,5813,5819,599,629,641,6516,6517,661,664,671, \\
672,673,674,675,676,677,678,679,681,682,683,684,685,686, \\
687,688,689 .\end{array}$ \\
\hline 3. Durable goods (and parts) & $\begin{array}{l}\text { Home appliances, consumer } \\
\text { electronics, vehicles. }\end{array}$ & Final or intermediate & Durable goods: 7241, 7242, 725, 731, 732, 735, 891. \\
\hline $\begin{array}{l}\text { 4. Technical progress diffuser } \\
\text { goods }\end{array}$ & Machinery, chemicals. & Capital goods or intermediate. & $\begin{array}{l}\text { Technical progress diffuser goods: } 541,553,7111,7112,7113 \text {, } \\
7114,7115,7116,7117,7118,712,7141,7142,7143,7149,715 \text {, } \\
717,718,719,722,723,7249,726,729,734,861,862,864,9510 .\end{array}$ \\
\hline
\end{tabular}

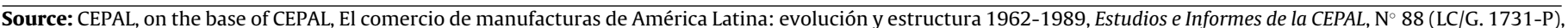

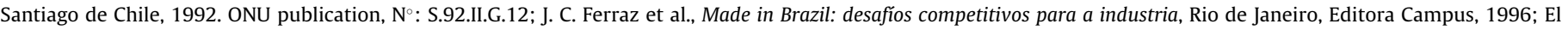

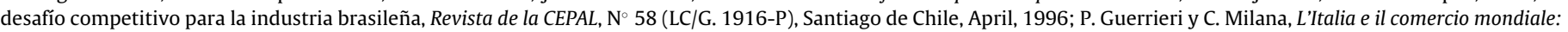
mutamenti e tendeze nella divizione internacional del lavoro, Roma, II Mulino, 1990.

a/CUCI = International Trade Uniform Classification, first version.

\section{Appendix B. Statistical data and variables}

\begin{tabular}{|c|c|c|c|c|c|c|c|c|}
\hline obs & MX_PBIP & MX_OPEN & MX_PRIM & MX_IND & MX_IND1 & MX_IND2 & MX_IND3 & MX_IND4 \\
\hline 1980 & 100,0 & 27,6 & 80,8 & 19,2 & 5,9 & 8,4 & 2,3 & 2,6 \\
\hline 1981 & 106,1 & 30,2 & 82,1 & 17,8 & 4,2 & 9,3 & 1,8 & 2,5 \\
\hline 1982 & 103,0 & 25,1 & 86,1 & 13,9 & 3,4 & 6,4 & 1,3 & 2,8 \\
\hline 1983 & 97,0 & 24,3 & 70,2 & 29,7 & 5,7 & 10,5 & 2,9 & 10,6 \\
\hline 1984 & 98,2 & 26,1 & 66,7 & 33,1 & 6,2 & 12,5 & 3,4 & 11,0 \\
\hline 1985 & 98,3 & 26,0 & 64,3 & 35,6 & 6,6 & 12,1 & 3,6 & 13,3 \\
\hline 1986 & 93,2 & 26,7 & 45,3 & 54,7 & 10,7 & 14,8 & 8,0 & 21,1 \\
\hline 1987 & 93,0 & 28,4 & 51,4 & 48,1 & 8,5 & 17,3 & 9,5 & 12,8 \\
\hline 1988 & 92,4 & 32,6 & 42,9 & 56,7 & 10,8 & 20,6 & 10,2 & 15,1 \\
\hline 1989 & 94,5 & 35,7 & 44,6 & 55,0 & 10,2 & 18,5 & 9,8 & 16,4 \\
\hline 1990 & 97,6 & 32,9 & 46,9 & 52,8 & 8,6 & 17,3 & 13,1 & 13,8 \\
\hline 1991 & 99,8 & 35,3 & 39,8 & 59,5 & 10,8 & 16,9 & 17,2 & 14,7 \\
\hline 1992 & 101,6 & 37,9 & 22,7 & 77,0 & 15,9 & 11,1 & 19,4 & 30,6 \\
\hline 1993 & 101,5 & 39,2 & 19,0 & 80,6 & 16,7 & 10,5 & 21,2 & 32,1 \\
\hline 1994 & 104,2 & 43,8 & 17,1 & 82,7 & 16,4 & 9,8 & 22,2 & 34,3 \\
\hline 1995 & 96,0 & 47,2 & 16,2 & 83,5 & 15,8 & 12,6 & 22,7 & 32,5 \\
\hline 1996 & 99,5 & 54,0 & 16,4 & 83,5 & 17,1 & 9,7 & 23,9 & 32,7 \\
\hline 1997 & 104,6 & 59,5 & 14,1 & 85,8 & 19,2 & 9,3 & 22,8 & 34,5 \\
\hline 1998 & 108,1 & 64,1 & 10,0 & 89,9 & 20,0 & 8,3 & 24,0 & 37,6 \\
\hline 1999 & 110,3 & 69,9 & 10,4 & 89,4 & 19,3 & 6,9 & 24,2 & 38,9 \\
\hline 2000 & 116,0 & 77,7 & 12,4 & 87,5 & 18,3 & 6,6 & 23,1 & 39,6 \\
\hline
\end{tabular}


Variables

\begin{tabular}{|c|c|}
\hline MX_PBIP & GDP per cápita (base $1980=100$ ) \\
\hline MX_OPEN & Trade opening (\% del PBI) \\
\hline MX_PRIM & Participation of primary exports (\%) \\
\hline MX_IND & Participation of industrial exports (\%) \\
\hline MX_IND1 & Participation of traditional industrial exports (\%) \\
\hline MX_IND2 & Participation of industrial exports with economies of scale (\%) \\
\hline MX_IND3 & Participation of durable industrial exports (\%) \\
\hline MX_IND4 & Participation of diffusers of technological progress industrial exports (\%) \\
\hline
\end{tabular}

Elaborated by the authors.

\section{Appendix C. Trends major variables, Mexico 1981-2000}

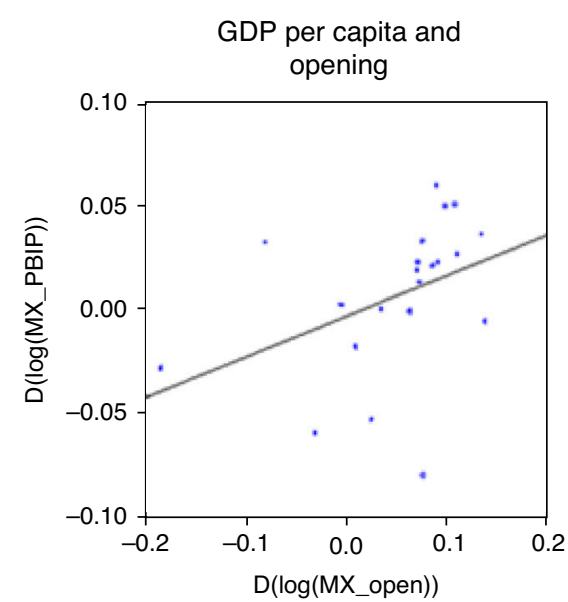

GDP per capita and primary exports

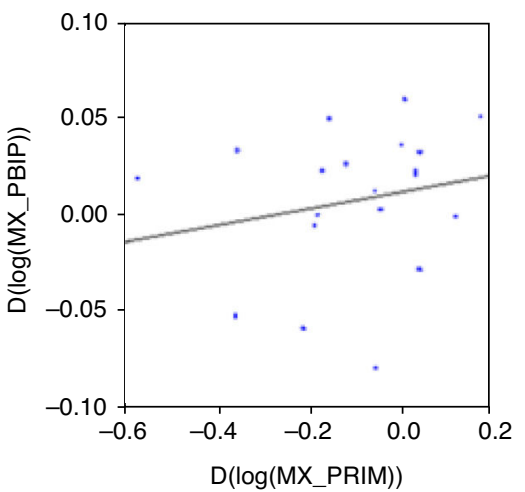

Elaborated by the authors.

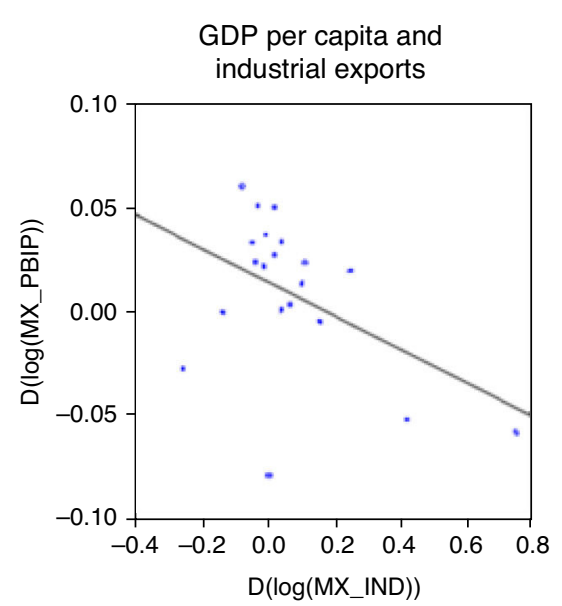

GDP per capita and industrial exporter with economies of scale

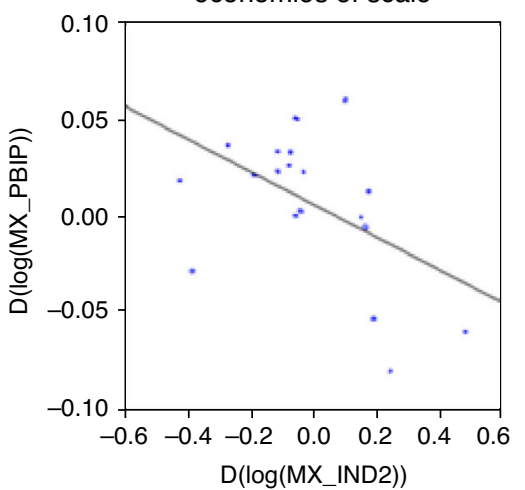

\section{References}

Alonso, J., Carrillo, J., \& Contreras, O. (2002). Enero-Junio. Aprendizaje tecnológico en las maquiladoras del norte de México. En Frontera Norte, 14(27), 43-82.

BID (2001). Competitividad, el motor del crecimiento: progreso económico social en América latina. Informe 2001. Washington, DC: BID, p.292.

Buitelaar, R., Padilla, R., \& Urrutia, R. (1999). Abril. Industria maquiladora y cambio técnico. Revista CEPAL, 67, 133-152.

Cepal (2003). Anuario Estadístico de América latina y el Caribe, 2002. Santiago de Chile: Cepal.

Cepal (2003a). Panorama de la inserción internacional de América latina y el Caribe, 2001-2002. Santiago de Chile: Cepal.

Dollar, D. (1992). April. Outward-oriented developing countries really do grow more rapidly: Evidence from 95 LDCs. 1976-85. Economic Development and Cultural Change.

Dollar, D. and A. Kraay (2001). Trade, growth, and poverty. World Bank Policy Research Working Paper.

Dollar, D. y A. Kraay (2003). Institutions, trade, and growth: Revisiting the evidence. World Bank Research.
Edwards, S. (1992). Trade orientation, distortions, and growth in developing countries. Journal of Development Economics, 39(1), 31-57.

Frankel, J., \& Romer, D. (1999). June. Does trade cause growth? The American Economic Review, 379-399.

Graham, F. D. (1923 February). Some aspects of protection further considered. The Ouarterly Journal of Economics, 199-227.

Krugman, P.(comp.)(1991). Una política comercial estratégica para la nueva economía internacional, México, DF: FCE, 303 pp.

Matsuyama, K. (1992). December. Agricultural productivity, comparative advantage, and economic growth. Journal of Economic Theory, 58, New York, Academic Press.

Mortimore, M., Vergara, S. and J. Katz (2001). La competitividad internacional y el desarrollo nacional: implicancias para la política de IDE en América Latina. CEPAL, Serie Desarrollo Productivo, 107.

Reinert, E. (2002). Junio. El rol de la tecnología en la creación de países ricos y pobres: el subdesarrollo en un sistema schumpeteriano. Cuadernos de Difusión, 12. Lima: Escuela de Administración de Negocios para Graduados, ESAN, pp. 7-36.

Roca, S. and L. Simabuko (1999). Diciembre. Value and quality creation: natural resources, industrialization and standards of living in Peru 1950 to 1997 
Cuadernos de Difusión, 9-10. Lima: Escuela de Administración de Negocios para Graduados, ESAN, pp. 69-123.

Roca, S., y L. Simabuko (2004) Natural Resources, industrialization and fluctuating standards of living in Peru, 1950-97: A case study of activity-specific economic growth, in Reinert, S. Erik (2004) Globalization, Economic Development and Inequality, Edward Elgar, 339 pp.

Romer, Paul (1990). Endogenous technological change, Journal of Political Economy, Vol. 98, No 5, The University of Chicago Press.

Ros, J. (2001). Abril. Política industrial, ventajas comparativas y crecimiento. Revista de la Cepal, 73, 129-148.
Sachs, J. and A. Warner (1995). Economic reform and the process of global integration. Brookings Papers on Economic Activity, (1), 1-118.

Sachs, J. y A. Warner (1995a). Natural resource abundance and economic growth Working Paper 5398, NBER.

Sala-i-Martin, X. (1997). I just ran two million regressions. American Economic Review, 87(1)

Unctad (2001). Informe sobre las inversiones en el mundo, 2001. Objetivo: fomenta las vinculaciones. Panorama general. Nueva York y Ginebra: Naciones Unidas, pp.81. 